REFLECTIONS:

NEUROLOGY AND

THE HUMANITIES

\title{
The case of the colorless crystals
}

Robert J. Joynt, MD, $\mathrm{PhD}$

Address correspondence and reprint requests to Dr. Robert J. Joynt, Department of Neurology, University of Rochester Medical Center, Box 673, 601 Elmwood Avenue, Rochester, NY 14642 robert_joynt@urmc.rochester.edu
I have often wondered at the depth of knowledge that Sherlock Holmes possessed on certain subjects, some quite arcane, and I have been equally amazed at his complete lack of knowledge in certain areas that most would consider commonplace. At one point, you will remember he had no notion of the Copernican theory, and dismissed my amazement, citing his notion of how the brain stored knowledge, that is, useless information would crowd out useful information. However, as my present narrative demonstrates, he had the uncanny ability, when faced by a problem, of ferreting out the appropriate paths to pursue and to find the key information necessary to the solution.

The interesting problem presented itself on a cool, crisp spring day. My surgery had been light that morning, my wife had gone off for several days to help one of her former schoolmates with a new baby, and Holmes had proffered me an invitation to dinner where we were to sample some bottles of a fine claret given to him.

I arrived in mid-afternoon, and I found Holmes looking out the window.

"Ah, Watson, it is good to see you, but it looks as if we are having an unexpected visitor. That fine looking young man is heading for our door."

Shortly, Mrs. Hudson ushered in our visitor.

The visitor greeted us with an apology, saying, "Sir, I am sorry to call on you without prior notice, but there is a problem of great urgency and delicacy that needs an explanation or many innocent people will suffer greatly. First, let me introduce myself as you know nothing about me."

"Please do," said Holmes. "Other than you were a corporal in the 21st Lancers, and were discharged after receiving a leg wound at the famous battle of Omdurman, we know nothing about you."

Our visitor was astonished, and said, "But, Mr. Holmes, no one could have given you those facts as the occasion of this visit was shared with no one."

I, of course, had seen similar performances like these in the past: the most memorable was the verbal duel that Holmes had with his brother Mycroft in the interesting case of the unfortunate Greek interpreter.

"Elementary, my good friend," said Holmes. "Your highly polished service shoes immediately established your recent status. Your bearing and demeanor suggested a person of some authority as a non-commissioned officer. Your comparative youth likely precludes an elevation to sergeant, hence a corporal. Your gait is that of a horseman and not a foot soldier, so you were likely in the cavalry. Your skin is still bronzed from exposure to the sun, which I assure could not have happened in our last dismal winter in England. The hitch in your otherwise well-measured gait suggests a recent injury. If you put these facts together it suggests that you were serving under General Gordon in the Sudan during the great battle at Omdurman this past September."

Our dumbfounded visitor said, "You were right on every score. But why the 21st Lancers?"

"That was a lucky guess, but as my friend Dr. Watson accuses me that it really is quite a simple exercise when you hear it explained, I usually embellish the observation to confound him. Besides, I read all the reports of the war from a Mr. Winston Churchill, an estimable young man, who was a correspondent accompanying the Lancers."

"Well, you do know something about me, but let me tell you about this very delicate problem. My name is George Tompkins, and I served under Lieutenant James Newcastle. He was the finest officer I ever knew - brave under fire, caring for his men, and, in spite of his rich upbringing, had simple tastes. He had a terrible bullet wound in the head at the great cavalry charge by the Dervish forces. I had my leg wound at the same time. He was immediately unconscious after his injury and eventually went to our base hospital. Everyone feared for his life, but in a few weeks he regained his senses. Fortunately,

The estate of Sir Arthur Conan Doyle has given permission to use character and place names that appeared in his original works. 
the regimental surgeon Captain Woodward, who cared for him, was his oldest friend and classmate at college. But the weakening effect of the injury was such that he was eventually dismissed from the service. I was at the same hospital, and, again, his kindness was such that he offered me a position as his valet until he fully recovered. As I had no prospects for a livelihood, it was a godsend until I had established myself back home and could seek further employment.

“Thus, I ended up at his parents' large estate just east of Cambridge. The parents, his older brother John, and the many servants were most kind to me. I found out that my employer was betrothed to a neighbor. Her name was Barbara Stewart, and she was the sweetest and kindest companion, who looked in every day, read to him, and saw that he had a long walk daily. They were a most happy pair and were a delight to see together.

"The estate, which is extensive, will go to John, the elder son. James, of course, is no longer fit for military duties, and his prospects for employment are not clear. This has been of great concern to him. It is this circumstance that led to the events of a week ago and the reason I have sought your assistance."

"Please," said Holmes, "all the details."

"Mrs. Newcastle has a large collection of very valuable jewels, which she keeps in her bedroom. Her family has been in the East Indian spice trade for years and was quite wealthy. She was the only child and inherited considerable wealth, including the jewelry. A week ago in the morning she found her jewel case broken into and the pieces were missing. The local police were called, and they immediately conducted a search of the household. One of the pieces, a minor one, was found in James' bedroom. This, of course, was very upsetting to the family, and James vehemently claimed he knew nothing about it. All, including the entire household staff and the estate manager Corbett, were then questioned. Unfortunately, the previous evening Maggie and Sarah, the upstairs maids, were in the hall preparing to turn down the beds and saw James come out of his mother's bedroom. They asked him whether they could be helpful in any way, but he brushed passed them without replying and went to his bedroom. They both remarked that he seemed quite anxious. They asked Corbett, who has an office on that floor, to go into the bedroom and check on him. Corbett did so, and he reported that James was in a deep sleep. James completely denies the encounter. Both of the maids have been employed for over fifteen years and have an unblemished work record. At the moment, the family is not pressing any charges, but you can imagine the distress that abounds."

Holmes thought for a moment, and then asked, "I take it that the family knows nothing of your visit?"

Tompkins answered, "They do not, but I will speak to them and see if they want you to come. If so, I will send you a telegram and book lodging for you at our local inn."

We left it at that, but a day later Holmes received a telegram inviting him to look in on the affair. It also mentioned that the local police inspector would be pleased to help him in any way.

The next day Holmes and I departed on an early train from King's Cross headed to Cambridge and the fen country. Holmes slumped in the corner of the compartment and I read the Times. At the Cambridge station, we were met by Tompkins with a carriage supplied by the Newcastle family. After a pleasant ride, we were put up in rooms in an attractive small inn, and, after a brief tea, were taken to the Newcastle estate. It was, as Tompkins had described, shrouded in disbelief and gloom. James had taken a setback in his convalescence, and was confined to his bed. Holmes talked to the family and the staff, and made a perfunctory search of the house and grounds. We ended up our day by visiting with James, who was distraught with grief and still denying any remembrance of the unfortunate and fateful occasion.

We returned to the inn, had a fine meal, and Holmes went over the facts with me. He was particularly interested in my assessment of the state of health of James Newcastle.

This inquiry brought back many painful memories of my time in Afghanistan and India, where I was seconded to the Berkshire Regiment. I said, "Holmes, I saw so many wretches like James Newcastle, fatigued by battle, then badly wounded, and discharged to a long convalescence if still living. I experienced some of this myself after my injury from a jezail bullet; it took me months to regain my strength."

Holmes asked, "How would you say young Newcastle is proceeding?"

"In my medical opinion, he still appears wan and anxious. You noted that on his bedside table was a large bottle of colorless crystals, likely potassium bromide, which, when dissolved in water, is an excellent nerve tonic and inducer of sleep. We used it frequently in the base hospital, and I 
had occasion to use it myself after my painful wound."

Holmes agreed, "Yes, I noted the medicine. But there is something wrong here; someone is hiding an essential fact. Watson, I propose we have an early breakfast, take a train to London, and I will make some inquiries."

Two days later, Holmes and I found our way back to Cambridge. We discussed the affair on the train, and Holmes laid out his plans for our next course of action.

Holmes said, "Watson, I hope to finish this today as I have received some information that is most helpful. As you know, fortunately, Dr. Woodward, James Newcastle's college friend and physician, is on leave, and is staying with friends at Caius College. If you would contact him, perhaps he would be more forthcoming about Newcastle's illness in discussing it with a medical colleague. In the meantime, Tompkins will meet me at the station and we will go to the Newcastle estate. I want to get more information from Corbett, the house and estate manager, about the past employment of the staff. Unfortunately, I also have to confront James Newcastle with an unpleasant truth, and I hope to get some useful information from him. We will meet at the booksellers' stalls in the town square at 4 o'clock. With our newly acquired knowledge, we can proceed from there."

Tompkins was as good as his word, and met us at the station. He dropped me at the city center, not far from Caius College, and proceeded with Holmes to the Newcastle estate.

I located Woodward very easily with some help from one of the college porters. I invited him to morning tea where we could converse more comfortably. He was pleasant enough, although uneasy, and not too helpful. He told me of James' wound, the critical time in the hospital, and the slow convalescence. He had visited James recently, and thought that his convalescence was slow but improving. When we finished up with the medical details, we had a general discussion about life in the military. He excused himself after an hour or so, saying he had another appointment. I spent the rest of the day wandering through the numerous bookstores, and taking a pleasant walk down the Backs along the Cam.

At 4 o'clock Holmes was thumbing trough some manuscripts at the bookstalls. We finally found a bench to share our information.

Holmes asked, "And what did you learn from Dr. Woodward?”

I indicated that there was almost no new knowledge of his injury and recovery, but I felt that he was not divulging all his observations.

Holmes replied, "I expected that would be the case. Watson, you are too gentle to be an effective inquisitor. Obviously, there is a covenant between the physician and the patient that Woodward would respect. However, I believe there is something even deeper. I think we should pay him another visit."

Woodward was in his room, finishing up his afternoon tea, and was surprised to see Holmes and me again. I introduced Holmes to him. Obviously, he had heard about him from his visits to the Newcastles.

Holmes took a folded sheet of paper from his pocket, handed it to Woodward, and said, "Dr. Woodward, I respect your friendship and personal relationship with James Newcastle, and you have acted in the most noble manner. However, I received this letter from James after explaining the dire consequences of his present difficulty, and he explained the situation to me. This letter is a request from him that releases you from your pledge of confidentiality about his illness. It is extremely important to him, his family, and his fiancée that you divulge all the elements of this situation."

Woodward read the letter and lowered his head into his hands for a few moments. He then straightened up, and said, "Thank you, Mr. Holmes, this terrible burden has been bedeviling me since it occurred. Let me explain it as well as I can, although there are still some puzzling matters that I do not understand. James had a very severe wound from one of the enemy mounted soldiers during this cavalry charge. Fortunately, he was removed almost immediately to the hospital where I was stationed. I recognized him as my old friend and classmate, and paid particular attention to his condition. His scalp was badly split, and the skull was fractured, although there appeared to be no extrusion of brain tissue. He was in a coma for weeks, but, gradually, consciousness returned. It was during this time that he experienced severe epileptic fits with a tetanic spasm of the limbs followed by jerking of the arms and legs. These would last several minutes and he would fall into a sound sleep after his exertion. I am sure that Dr. Watson in his experience has seen the same phenomenon."

I nodded. "I have seen it much too often."

Woodward continued, "Prescribed treatment for this disorder was potassium bromide crystals dissolved in water. Fortunately, either due to the medication or to time, the seizures decreased. 
However, they were replaced by another type of spell of which I was not familiar. James would occasionally rise up in his bed, he seemed conscious, he would walk aimlessly around the hospital ward and not speak, and would wander back into his bed, and would fall into a deep sleep. My fellow officers had never seen anything quite like this."

Holmes looked up and then interjected, "Perhaps I can help you. A few days ago, I met with Dr. Hughlings Jackson. I had previously met him at the Diogenes Club with my brother Mycroft. $\mathrm{He}$ is a nerve specialist; he impressed me with his vast fund of knowledge, and his imaginative views on how the nervous system works. He was kind enough to let me speak with him at his consulting rooms. At that time I went over the situation with James Newcastle. He quickly informed me that the use of potassium bromide crystals for the treatment of epilepsy was reported in 1857 by Sir Charles Locock who, I believe, was the physician accoucheur to our own dear Queen. It is used frequently in medical practice for many patients with epilepsy, in addition to its use as a nerve tonic and inducer of sleep.

"I described the peculiar behavior of James Newcastle on the night of the theft. He concluded that this could be a form of epilepsy, or a cerebral paroxysm, as the preferred to call it. He noted that most people, including the medical profession, looked upon epilepsy as a state of stiffening and violent shaking of the extremities with loss of consciousness. He believed that the paroxysm could take place in different parts of the brain and that peculiar mental states could be induced during the attack.

"He pointed out that he had followed such a case for years and kindly supplied me with a portion of an article he wrote in the medical journal Lancet, 1894, ii, p. 252.

"Here is a portion of that report. I wonder if you would be so kind to read it aloud, Dr. Woodward?"

Woodward took the proffered paper, and read: "A man, aged 28, consulted me on September 28, 1883, for epileptic fits, or, as I prefer now to say, cerebral paroxysms; he had been subject to them for six years. These attacks only came on, he said, when he was 'at his best,' and when he was asleep or when he was composing himself to sleep in the day. He had a warning of noise in his head, and then 'hearing goes' and he 'loses his senses' (tongue bitten). But besides these attacks of severe fits he had, to use his words, 'partial and transitory losses of understanding'; these were, of course, attacks of epilepsy (cerebral paroxysms) also, although, slight ones. The interest of the case is in the slight seizures. When I first saw him he had a 'warning' of a slight seizure by a buzzing noise and became 'deaf,' but yet he explained that neither hearing nor sight was affected, but that he was unable to understand what was said to him and he was unable to express himself, and he was, as we shall see, unable to read."

Here, Holmes held up his hand, and continued, "I think that is the crux of the problem. The doctor thought the history of the head injury, the initial epileptic attacks, and the peculiar nature of the spells, suggested to him that Newcastle's behavior likely was a 'slight seizure,' a type of cerebral paroxysm. It would also explain Newcastle's denying of the event. Although he could not be certain, he thought that time and judicious use of medication would improve the state of the patient."

Dr. Woodward brightened up, and said, "I certainly think that explains James' behavior on that evening. But what about the piece of evidence found in James' room?"

Holmes smiled. "I think I may have solved that problem. On my return from the Newcastle estate to Cambridge, I communicated with the local police, and I would guess that the thief has been taken into custody. Woodward, I suggest that you have a meeting with the family, and now that you are released from your confidentiality, I propose you explain the total situation to them. Watson, you look distraught even when we have come to a likely solution.”

Watson replied, "I recognize that, and I am pleased. But it seems inconceivable to me that in this day of supposed enlightenment that poor Newcastle must hide his illness or be stigmatized by the public, including his family and fiancée. An illness caused by his heroic service to the Crown."

Holmes nodded in agreement. "You are absolutely correct. Perhaps, in the future. .."

Woodward agreed to visit the Newcastles as soon as possible. Holmes and I excused ourselves and took an evening train back to London. On the trip back, I admonished Holmes that he had not shared the complete solution with me.

Holmes smiled, and said, "I am not completely certain of the outcome, but if my powers of reason have not completely left me, the culprit was Corbett. You remember, he went into James' room at the behest of the two maids, and reported that James was in a deep sleep. I had gone over the previous records of the household and noted 
that Corbett had been an apothecary's assistant for three years. It is likely he noted the potassium bromide crystals on the bedside table. He might not have known they were specifically for treating epilepsy as James had not had a previous attack while at the estate. However, he knew they were for some type of mental agitation and took advantage of the occasion. Likely, we will soon know, Watson."

My wife had not yet returned. Holmes was kind enough to provide lodging for me the next few days where I could enjoy his company and, also, I could enjoy the fried kippers for breakfast prepared by Mrs. Hudson.

In a few days, Holmes had a long letter from Mrs. Newcastle, which he handed over to me to read after removing a bank draft, which he put in his side pocket. The letter read:

"My dear Mr. Holmes, our gratitude to you is unbounded. Dr. Woodward explained the whole situation. The police did another exhaustive search of Corbett's room, and found all the jewelry. My husband and I have more than ample means and decided to settle the estate immediately on John. John insisted that the largest farm on the estate be given to James to ensure an income. James has asked Tompkins to stay on as farm manager, and Tompkins has accepted. Barbara has set an early wedding date, and we are delighted at the match. Corbett will learn of his fate at the next meeting of the assizes. We can never repay you, but are enclosing something with our deepest gratitude for your services. Sincerely yours."

Holmes said, "As your wife will not return until tomorrow, I will take you down to the Strand where we will go to the finest restaurant and have a Lucullan feast of Dover sole and the best accompanying wines."

I protested. "Holmes, that is too extravagant." Holmes chuckled, patted his side pocket, and said, "Watson, I assure you that the gratitude of the Newcastles will reimburse us fifty times over for our extravagance. It will also afford us an opportunity to toast the valued assistance of Dr. Hughlings Jackson.” 


\section{Neurology}

\section{The case of the colorless crystals}

Robert J. Joynt

Neurology 2007;69;931-935

DOI 10.1212/01.wnl.0000267841.86249.fa

This information is current as of August 27, 2007

\section{Updated Information \&} Services

Citations

Permissions \& Licensing

Reprints including high resolution figures, can be found at: http://n.neurology.org/content/69/9/931.full

This article has been cited by 1 HighWire-hosted articles: http://n.neurology.org/content/69/9/931.full\#\#otherarticles

Information about reproducing this article in parts (figures,tables) or in its entirety can be found online at:

http://www.neurology.org/about/about_the_journal\#permissions

Information about ordering reprints can be found online: http://n.neurology.org/subscribers/advertise

Neurology ${ }^{\circledR}$ is the official journal of the American Academy of Neurology. Published continuously since 1951, it is now a weekly with 48 issues per year. Copyright. All rights reserved. Print ISSN: 0028-3878. Online ISSN: 1526-632X.

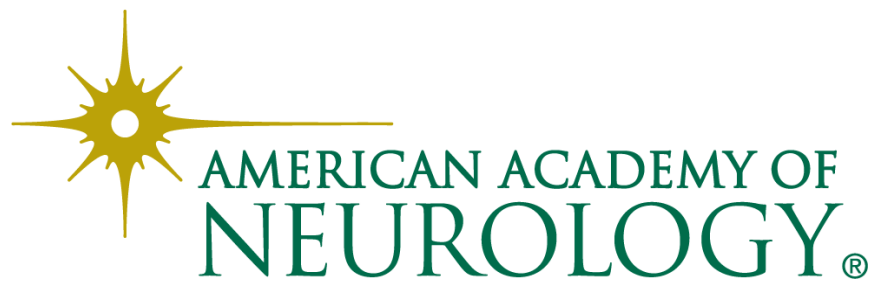

